\title{
SCIENCE IN WAR AND PEACE*
}

\author{
By SIR HENRY DALE, O.M., G.B.E., F.R.S.
}

$\mathrm{T}$ HE officers and Council of the British Association have naturally wished that this meeting should take special note of the emergence of science, in Britain as in other countries, from its abnormal concern with war, and its return to the service of peace. To rally and to give direction to the thoughts of the members and of the sectional officers in this general sense, the phrase 'Swords into Ploughshares' was suggested, and adopted by the Council, as a motto for the meeting. Even in its most obvious meaning, of the direct adaptation to peaceful uses of the practical results of researches made to meet the demands of war, or forced into rapid fruition by the heat of its urgency, the metaphor will find abundant application in this week of discussions. Let me choose a few, almost at random, for mention now.

How many decades of research do you suppose, undertaken in response to no stimulus stronger than the desire to add to the resources of peace, would have been acquired for those developments of radar, which were achieved in a few years under the imminent threat and the realized peril of war? It is certain that the scientific activities of peace had never witnessed anything like the intimate collaboration of British and American physicists and engineers, which finally played so important a part in giving full effect to this triumph of science in the service of war.

Aeronautical scienee, having received a great stimulus in the First World War, and having undergone a steady development in the intervening years, sprang again into a phase of headlong progress under the threat and the experience of the Second World War. Now we wait to see what will be the effects, on speed and safety in peaceful transport, of gas-turbine engines and jet propulsion, of stratosphere flight in pressure cabins, and of the fundamental changes in aircraft design, which are all still under rapid development.

Sir Alexander Fleming had encountered the first evidence for the existence of penicillin and described the general nature of its action in 1929, ten years before the War began; but, during that interval, its interest had remained little more than that of an item in the natural history of moulds and bacteria. Sulphanilamide and its derivatives, meanwhile, had opened a new vista of chemotherapy for the bacterial infections, and gramicidin had provided an example of a natural antiseptic, an 'antibiotic of practical potentialities; but exploration, in this field also, was to wait for war's demands to give it a full and urgent acceleration. And we cannot doubt that the wider survey by Sir Howard Florey and his team, which led them, in 1939 , to take penicillin down from the shelf of sound but unexploited observation, for the new study which brought it so rapidly into practical use, owed some of its stimulus to the gathering menace of war. We may certainly assume that the lavish character of the industrial research and enter prise, which then so quickly overcame the difficulties of manufacturing penicillin on a large scale, was chiefly due to recognition of the part which it would play in the conduct of the War. This industrial

* Substance of the Presidential Aduress to the British Association for the Advancement of Science delivered at Dundee on August 27. production, again, made penicillin, and then several penicillins, more rapidly available for the purely scientific investigation of their structures. Here, again, the conditions of peace have never produced such a remarkable co-operative effort of research as that in which teams of some of the leading chemists of Britain and of the United States pooled their results, solved the difficult structural problem with what, by normal standards, would have been an astonishing rapidity, and even, in the case of one of the penicillins, confirmed by synthesis the structure to which the less-direct evidence had pointed.

French, British and Italian investigations had all contributed to the discoveries which had identified the blood parasites causing the malarial fevers, and revealed the manner of their transmission by mos. quitoes, all before the present century began. Little more than detailed advance, on the other hand, had been made in the curative or preventive treatment of malaria by medicines since the seventeenth century. Cinchona and its chief alkaloid, quinine, had continued to provide the standard medicinal treatment, although, between the Wars, the research enterprise of German industry had produced two new artificial remedies. One of these, indeed, known as atebrine, and later in Britain as mepacrine, was understood to be comparable in action to quinine, though there had been no sufficient inducement to its extensive trial as a substitute. It was fortunate, then, that, as a military precaution, the effective manufacture of mepacrine had been undertaken in Britain, and then in the United States, before Japan seized, in the East Indies, the source of most of the world's supply of quinine. Under the continued stimulus of war's demand, again, a new campaign of chemotherapeutic research was opened in both Britain and the United States, to seek yet better remedies than quinine or mepacrine. Again there was a co-operative exchange of information and materials between the workers in both countries, and the investigation was conducted on such a scale and with such organisation of effort as had never been contemplated in peace. In a surprisingly short time came reports of new lines of development showing great promise; and a British one of these has culminated, so far, in the discovery of paludrine, a synthetic antimalarial substance of a new type, more effective, and at the same time much freer from harmful accessory activity than quinine, or mepacrine, or any other of its predecessors.

The needs of war, again, soon presented to engin. eering, on one hand, and to physiology and experimental psychology on the other, a group of practical problems arising from the unnatural conditions of physical and mental stress to which men were exposed in the constantly developing machines of modern warfare, as well as from the extremes of climate and the deprivations to which they were subjected by military necessity or accident. The researches which were framed and conducted, in response to these varying demands, have produced a great volume of new knowledge concerning a variety of conditions which favour or hinder the different activities of man's body and mind, and their resistance to the influence of fatigue. 
Not all the uses of war-time discoveries in peace will depend on applications so direct and obvious. There are examples already, and it is most likely that more will appear, of inventions made with no purposes but those of war, which have found peaceful use in directions entirely unforeseen. For example, an artificial chemical substance, di-isopropylfluorophosphonate, now commonly known as D.F.P., was first made and studied in Britain, as an active member of a poisonous series, known to be under trial in Germany as potential weapons of chemical warfare. The actions of D.F.P., some of them unpleasant enough, were found by workers in Britain, whose results were later confirmed by colleagues in the United States, to be due to its power of annulling the action of cholinesterase-an enzyme widely distributed in the animal body, and playing an important part in relation to the transmission of a number of nervous effects. D.F.P. was never used, in fact, as a chemical weapon; but the action which might have led to such employment has already made it, not only a most interesting and valuable tool of physiological research, but also, according to recent news from the United States, an invaluable remedy, when suitably administered, for the dangerous paralysis of the intestine which may follow an operation. So the wheel has come full circle, and the sword, forged as a lethal weapon, finds use, not only as a ploughshare of peaceful research, but even as a shield for threatened lives.

The sectional meetings during the week will certainly have under discussion many more of such direct applications and extensions of discoveries and inventions made in war to the ordinary needs and purposes of peace. These will constitute, however, only a part, and very likely not the most important part, of the incidental and compensating gains of science itself, and of mankind through science, from this participation in the researches required by war. Scientific research may expect to obtain, from inventions thus made for special and quite unrelated purposes, new tools and facilities for the general advancement of natural knowledge over wide ranges. The development of rockets as weapons of extreme range, for example, may provide means for obtaining data of physical conditions, at altitudes from the earth's surface previously far beyond the reach of scientific exploration; and the great advances made in aerial photography will certainly find application for purely scientific surveys of various kinds, over land and sea. And, apart from many and great additions of this kind to the physical and technical resources available to research, there will be lessons to be learned from war's experience of the methods of planning and organising research, of the recruitment of special research teams, of the value. for the rapid attainment of a particular objective, of cooperation on a national and, as in cases which I have quoted, on an international scale.

Scientific method hàs had new opportunities of demonstrating its value in the range of the so-called 'operational' researches, in which, for the first time in any war, a largely successful effort was made to collect, and to subject to scientific analysis, accurate data of the performance of new weapons, and of the outcome of new methods. All such experiences in war will have left lessons which may have value in peace, to science in the pursuit of its normal objectives, and to the world at large in a new understanding of what science can be expected to do, and of the kind of aid it can offer towards the solution of suitable problems.
While we may well be eager, however, to ensure that science and those who cultivate it should thus retain and exploit the lessons of value which they learned in their service of war, it may be of at least equal importance that they should, with all rapidity and thoroughness, forget others which ought to be discarded. It is scarcely to be doubted that, to many men of science, the War brought opportunities for research under conditions which made it, in various ways, and in spite of the strain and anxiety of the time, more immediately attractive than any that they had previously encountered. Comradeship, effective even across some national boundaries, in work for a great cause, without thought of personal credit or recognition; an escape, perhaps, from indecision concerning the scientific worth or soundness of a line of personally chosen research, and from anxiety as to material resources for its pursuit, into a world of authority and planning, of problems posed by actual emergencies, of practical issues and tangible results, and of facilities without restriction; and a sense withal of high duty performed for the future of his country and of the world, by the use of a man's own special knowledge and skill, and not always without danger-duty as clear and unquestionable as others could only discharge by a sacrifice of all their normal instincts and interests and, for many, of life itself-all these conditions of scientific war service may have given to many a man a different kind of satisfaction from any which had come to him from the normal experience of a man of science in peace.

I suggest that there may be danger to science from a tendency to transfer too easily and completely, to the activities of peace, the attitude to research and the traditions of its conduct which have been acquired during six years of such war experience.

I am not, of course, speaking just now of the perversion of science which war research involves through its particular concern with the means of slaughter and destruction. For the moment I am concerned with the fact that the response to war's demands has led the majority of scientific workers of Great Britain to devote nearly the whole of their thoughts and efforts, during six years or more, to practical problems presented to them for rapid solution. There must, indeed, be many younger men who have had little experience of other kinds of research than that which has been thus directed and restricted to near and practical objectives, and carried out under a pressure of urgency. From Government organisations and industry, awakened by war's experience to a fuller awareness of what science can do for them under such conditions, it is not likely that encouragement will be lacking for a continuation of similar activities into peace. I myself, indeed, have been bringing to your notice the claims of lines of research which had proved fruitful of practical result for the purposes of war, to be continued and developed now, with a new orientation, to serve those proper to peace. I must make it clear, then, that it is far from my intention to suggest a predominance, in the programmes now to be shaped for science, of such transference to peaceful uses of the research enterprises of war and the methods by which they have been conducted.

Does anyone doubt that, to enable science to render its best service to mankind, we need now to take a long-range view and to give our first care to the extension of fundamental knowledge, unconstrained by aim at any prastical objective? I am not here 
concerned to advocate, or to defend, either of the rival philosophies, postulating the advancement of pure knowledge on one hand, or the material betterment of man's lot in the world on the other, as the ultimate true motive of the scientific effort. I believe that it would be admitted, by partisans of either, that research which seeks only to advance pure knowledge commonly leads, in the end, to the widest practical developments; and examples are to be found of the contrary, when practical researches are conducted under conditions which leave full freedom to follow fundamental issues, as these present themselves. The concentration, however, of practically the whole of a rapidly growing scientific effort on practical applications and developments, such as the War has witnessed, might find instructive analogy in a rapid and even reckless extension by a commercial undertaking of its trading enterprise, without care to conserve and proportionately to expand its resources of working capital. In theory I think that this is generally recognized, and I am not assuming that any of the different authorities which now provide material support for science in peace will hesitate to give generous encouragement to fundamental researches. My fear is rather that we men of science may find it difficult to shake off quickly the spendthrift habit in research, the policy of trading for quick returns, which six years of war experience may so easily have fostered.

There are other directions in which, I suggest, we should be alert and watchful against too ready an acceptance of lessons learned in war research as applicable directly to the needs of science now. The world never possesses at any time too many men of the highest kind of qualification for research in science-men who, by their own personal effort and achievement, can exert a determinant influence on the rate and the direction of the advance of know. ledge into the unknown, and can open new fields of science to detailed exploration by others. There may be men of that type who found that, in the years of war, they could give their best service to science, as well as to the nation and to the cause for which it stood and fought, by organising and planning researches for teams of men with narrower experience and outlook, and by bringing scientific methods to bear on problems of military policy. I believe that scientific services of that kind, rendered in war, have earned far more than they will ever receive in the way of acknowledgment; but I venture to voice a hope that men with the rare, creative ability that science needs now for the resumption of its normal progress, whose influence and example are needed in the schools for the inspiration of those who will follow, will not too readily assume, or too easily be persuaded, that their best service to science will still be rendered by planning and organising, or by bringing scientific ideas to bear upon policy. Here, again, I believe that, under conditions now to be faced, the building up of our scientific capital of fundamental knowledge by those who have the creative gift should have a prior claim over its practical exploitation and the cultivation of its political influence.

There are many, I think, who will be remembering with me the mood which prevailed among men of science when the First World War ended in 1918; how we looked forward then with eager hope and confidence, ready to write off the losses and delays which those four years of war might have inflicted on science, and determined to conserve for it all that could be counted as gain. The role of science in that War had, indeed, been relatively small. For the general body of men of science it had begun on a basis of opportunist intervention or response to special appeal, to deal with emergencies as these arose, the country's scientific reserves being called upon tardily and never completely enrolled. And, when victory came in 1918, the men of science, with few exceptions, were able quickly to escape from war's abnormal duties and commitments, and to return rejoicing to the free air and the wide horizons of science, as they had known it earlier in peace. Lessons had been learned then, as now ; the Government and public opinion had gained a new conception of the support of scientific research as a national investment; but thoughts of war, and of its claims on science, receded rapidly then into the background. And although what was to have been a permanent peace proved, in the event, to be less than two decades of an uneasy armistice, with the shadow of another war then rapidly encroaching, what a wonderful new flowering of science was witnessed in that short interval !

Think of the speed and completeness with which our ideas of the universe of matter, of atoms and of the ultimate, subatomic particles, of elements and their mutability, were then being recast; of the transformation, as rapid and impressive, of concep. tions of the life process and its physico-chemical background by the advances then being made in organic and physical chemistry, with biochemistry in ever more intimate alliance with them; of the new worlds of knowledge and ideas which were then being opened by the linking of genetics and nuclear cytology, giving a physical basis to the complexities of heredity; or of the first systematic study of the properties of ultramicroscopic viruses, linking, in a manner still mysterious, the characters of matter in macro. molecular solution with those of the smallest living and self-propagating organisms. From all these, and from fundamental advances of comparable rapidity and significance in almost all fields of scientific activity, rich harvests of new development and extension were continuously being reaped, by medicine, agriculture, industry, and all branches of applied science. Never, surely, in all previous history, had science surged forward with such impetus as in that interval of years when, in spite of recurrent economic and international crises, a lasting peace seemed still not beyond hope, and a golden age, for a world entering the scientific era of its history, a not impossible aspiration. And, for science itself, one of the points of brightest hope and encouragement was to be found in the steady rebuilding in that interval, in spite of initial obstacles and discouragements, of a true world community of science.

We know how tragically that interval of optimism and of free progress in science, so rapid and so various, came to an end. We cannot expect or even encourage a quick revival of that earlier mood. We are faced now by the contrast between the parts played by science in the two World Wars. In that from which we recently emerged, science, no longer a mere accessory, has moved right into the centre of the picture; and by a process of which we may, perhaps, find the tentative beginning in 1915, with the first use of chemical warfare as a weapon of mass slaughter and disablement, the belligerent use of science has undergone a rapid transformation, turning it into a weapon and a combatant in itself, released from afar for the undiscriminating infliction of death 
and destruction, at rapidly growing ranges and on an ever increasing scale. The atomic bombs on Hiroshima and Nagasaki represent, of course, the proximate peak of this development, so far as it has yet been made known; but nobody can suppose them to be the climax of disastrous achievement, if the nations should persist in the desperate project of using further advances in this, or in any other department of science, to prepare in secret, each to excel or to anticipate others in perfecting the means of annihilation. Does the world need yet to be warned as to the end of such a policy? If so, we men of science must continue, against any reluctance to repeat and to insist, to proclaim the danger, and our hatred of the perversion of science to its creation.

Meanwhile we have our own problem of the effect of such a position on the prospect of science itself. For a devotion so complete to the service of war as that which was given in recent years has involved many men of science during its progress in obligations of secrecy entirely new to their experience; and there are important sections of scientific activity which have not yet been able to escape from these trammels. That concerned with the release of atomic energy, with all the side-issues into new lines of scientific progress which that gigantic war enterprise might have made, and will yet, we hope, make available, provides the most conspicuous case. This might, indeed, be regarded as epitomizing, or presenting, by way of an extreme example, the way in which science in peace may inherit opportunities from developments for which war alone could have set the scale and provided the momentum, and the threat to the freedom of seience which may be entailed by the same inheritance. Though the scientific basis for its prediction was available in 1939, before the new War broke out, nothing but war, and the need to anticipate a danger of such magnitude in war, could have brought about an effort on the scale needed to convert the release of atomic energy by a chain-reaction from theory to practical reality in a few years. If peace had remained unbroken, the world might have had to wait for many decades to reach a point of such possibilities, for new departures and rapid advances in a whole range of fundamental sciences. War immensely accelerated the presentation of this opportunity to science; but, in doing so, compromised the peaceful use of it by the hideous threat of its further abuse in war. Science, then, finds itself facing a situation in which hope and frustration contend; the need to make the world safe, and the delay of agreement on the means of doing so, clog wheels of science which should now be turning freely for the enlightenment of mankind and the enrichment of human life, many years, perhaps many decades, before they could have done so if the War had not yet come.

How then are we men of science to deal with such a situation? With unquestioning loyalty to all our obligations-that first and foremost; but then also, I would urge, with a resolute watchfulness against any encroachment, on activities proper to peace, of a secrecy which we accepted as an abnormal condition in war, and with a determined effort to accelerate the liberation of science from its entanglement. In the universities in particular I hope that we shall be able to ensure that the men of science of the near future will grow up, as we their predecessors did, in an atmosphere of scientific freedom, and be ready to accept, in their turn, the duty of standing, at need, in the defence of science in its full integrity. And I hope that we can keep as the constant aim of our endeavour, in spite of all that might excuse discouragement, the revival of an intimate brotherhood of the men of science of all nations, working together in full confidence, once more as a world community.

\section{SUMMARIES OF ADDRESSES OF PRESIDENTS OF SECTIONS}

\section{EARTH, STARS AND RADIO}

$\mathrm{D}$

URING the year 1947 we are celebrating in Great Britain two important jubilees, one technological and the other scientific. It was in 1897, fifty years ago, that Marconi, the young Italian inventor, gave a decisive demonstration of 'telegraphy without wires' to Sir William Preece, who was then engineer-in-chief of the British Post Office. It was also in 1897 that the Cambridge professor of experimental physics, Prof. J. J. Thomson, made the first public announcement, at an evening discourse at the Royal Institution, of the existence of the electron as an independent entity. The technological development of radio from those early beginnings has had most important scientific consequences. Correspondingly, the scientific discovery of the electron, although important in the first instance because of its bearing on atomic theory, has had profound technological consequences. Indeed, it is scarcely possible to cite better examples of the mutual influence of fundamental science and technology than the developments which have sprung from those two great events of fifty years ago. These developments form the subject of the presidential address by Sir Edward Appleton to Section A (Physical Sciences).
The progress of radio as an agency for exploring the universe has followed directly from two electronic developments, namely, the thermionic valve and the cathode ray oscillograph. With the thermionic valve it is possible to generate radio waves of almost any wave-length. Moreover, such waves, if sufficiently short, can be emitted or received in any desired direction. It is also possible to arrange that their emission takes place in spurts, or pulses, which can be detected again if the waves are reflected by any natural agency in space. The cathode-ray oscillograph can, on the other hand, be used for the measurement of short radio echo-delay times, and also for the delineation of the wave-form of naturally occurring radio transients.

Using such radio and electronic techniques, the wave-forms of atmospherics, originating in lightning flashes, have been studied in some detail, and instantaneous methods have been developed for finding thunderstorm positions at a distance. Similarly, the use of centimetric wãve radar echoes has led to methods of estimating the extent of rainfall areas.

During the War it was discovered that coastal radar stations sometimes received echoes from a ship which had passed well beyond the horizon. The detailed examination of this connexion between 